\title{
FAMILY RELATIONSHIPS, JUVENILE DELINQUENCY, AND ADULT CRIMINALITY*
}

\author{
JOAN MCCORD \\ Temple University
}

Home observations during childhood and criminal records 30 years later are used to address questions of relative impact among features of child rearing influencing male criminal outcomes. The results suggest two mechanisms: Maternal behavior appears to influence juvenile delinquency and, through those effects, adult criminality. Paternal interaction with the family, however, appears to have a more direct influence on the probability of adult criminal behavior.

\section{THEORETICAL PERSPECTIVE}

Historically, family interactions have been assumed to influence criminal behavior. Plato, for example, prescribed a regimen for rearing good citizens in the nursery. Aristotle asserted that in order to be virtuous, "we ought to have been brought up in a particular way from our very youth" (Bk.II, Ch. 3:11048). And John Locke wrote his letters on the education of children in the belief that errors "carry their afterwards-incorrigible taint with them, through all the parts and stations of life" (1693:iv).

Twentieth century theorists ranging from the analytic to the behavioral seem to concur with the earlier thinkers in assuming that parental care is critical to socialized behavior. Theorists have suggested that inadequate families fail to provide the attachments that could leverage children into socialized life-styles (e.g., Hirschi, 1969). They note that poor home environments provide a backdrop for children to associate differentially with those who have antisocial definitions of their environments (e.g., Sutherland and Cressey, 1974). And they point out that one feature of inadequate child rearing is

- This study was partly supported by U.S. Public Health Service Research Grant MH26779. I thank Richard Parente, Robert Staib, Ellen Myers, and Ann Cronin for tracing the men and their records; Joan Immel, Tom Smedile, Harriet Sayre, Mary Duell, Elise Goldman, Abby Brodkin, and Laura Otten for coding the follow-up. I also express appreciation to the Massachusetts Department of Probation, the New York Division of Criminal Justice Services, the Maine Bureau of Identification, and to California, Florida, Michigan, New Jersey, Pennsylvania, Virginia, and Washington for supplying supplemental data about the men. In addition, I thank the anonymous reviewers whose criticisms have greatly improved the product. Only the author is responsible for the statistical analyses and conclusions. 
that it fails to reward desired behavior and fails to condemn behavior that is not desired (e.g., Akers, 1973; Bandura and Walters, 1959).

Over the past several decades, social scientists have suggested that crime is a product of broken homes (e.g., Bacon et al., 1963; Burt, 1925; Fenichel, 1945; Freud, 1953; Goode, 1956; Murdock, 1949; Parsons and Bales, 1955; Shaw and McKay, 1932; Wadsworth, 1979), maternal employment (e.g., Glueck and Glueck, 1950; Nye, 1959), and maternal rejection (Bowlby, 1940, 1951; Goldfarb, 1945; Newell, 1934, 1936). Some have linked effects from broken homes with the impact parental absence has on sex-role identity (Bacon et al., 1963; Lamb, 1976; Levy, 1937; Miller, 1958; Whiting et al., 1958), and others have suggested that parental absence and maternal employment affect crime through contributing to inadequate supervision (e.g., Dornbusch et al., 1985; Hirschi, 1969; Hoffman, 1975; Maccoby, 1958; Nye, 1958).

Despite this long tradition, empirical support demonstrating the link between child rearing and criminal behavior has been weak. Accounting for this fact, Hirschi (1983) suggested that attributing behavioral differences to socialization practiced in the family is "directly contrary to the metaphysic of our age" (p. 54). Hirschi criticized the few studies that refer to family influences for using global measures of inadequacy, noting that they cannot yield information about the practices or policies that might reduce criminality.

Most of the evidence made available since Hirschi's appraisal has depended on information from adolescents who have simultaneously reported their parents' behavior and their own delinquencies (e.g., Cernkovich and Giordano, 1987; Hagan et al., 1985; Jensen and Brownfield, 1983; van Voorhis et al., 1988). Because these studies are based on data reporting delinquency and socialization variables at the same time, they are unable to disentangle causes from effects.

Two studies based on adolescents' reports have addressed the sequencing issue. Both used data collected by the Youth in Transition project from adolescents at ages 15 and 17 years (Bachman and O'Malley, 1984). Liska and Reed (1985) looked at changes in delinquency related to parent-adolescent interaction; their analyses suggest that friendly interaction with parents (attachment) retards delinquency, which in turn, promotes school attachment and stronger family ties. Wells and Rankin (1988) considered the efficacy of various dimensions of direct control on delinquency; their analyses suggest that restrictiveness, but not harshness, inhibits delinquency. Although the same data base was used for the two studies, neither considered variables that appeared in the other, so the issues of relative importance and of collinearity among child-rearing parameters were not examined.

Relying on adolescents to report about their parents' child-rearing behavior assumes that the adolescents have correctly perceived, accurately recalled, and honestly reported the behavior of their parents. There are grounds for questioning those assumptions. 
Experimental studies show that conscious attention is unnecessary for experiences to be influential (Kellogg, 1980); thus adolescents may not notice salient features of their socialization. Studies have shown that reports of family interaction tend to reflect socially desirable perspectives (J. McCord and W. McCord, 1962; Robins, 1966; Weller and Luchterhand, 1983; Yarrow et al., 1970); thus adolescents' reports reflecting this bias would tend to blur real differences in upbringing.

In addition, studies of perception and recall suggest that reports about child rearing are likely to be influenced by the very features under study as possible consequences of faulty child rearing. For example, abused children tend to perceive their parents as less punitive than revealed by objective evidence (Dean et al., 1986; J. McCord, 1983a); aggressive children tend to perceive behavior justifying aggression (Dodge and Somberg, 1987); and painful experience tends to exaggerate recall of painful events (Eich et al., 1990). Yet, criminologists have paid little attention to measurement issues related to ascertaining the impact of socialization within families.

Studies of the impact of child rearing suffer from special problems. When the source of data is children's reports on their parents' behavior, effects and causes are likely to be confounded. When parents report on their own behavior, they are likely to have a limited and biasing perspective and to misrepresent what they are willing to reveal. These biases have been shown in a study that included home observations as well as mothers' reports. The child's compliance was related to observed, although not to reported, behavior of the mother (Forehand et al., 1978). Eron and his coworkers (1961) discovered that even when fathers and mothers reported similarly about events, "the relation to other variables was not the same for the two groups of parents" (p. 471). Additionally, regardless of the source of information, if data are collected after the onset of misbehavior, distortions of memory give rise to biases.

Attention to problems of measurement characterize two studies of juvenile crime. In one, Larzelere and Patterson (1990) combined interviews with the child and his parents, observations, and the interviewer's impressions to create measures of discipline and monitoring. They found strong collinearity and therefore used a combined measure of "parental management." Data on family management were collected when the children were approximately nine years old. This variable mediated a relationship between socioeconomic status and delinquency as reported by the boys when they were 13. Larzelere and Patterson acknowledge that their measure of delinquency may be premature, but they point out that early starters tend to become the more serious criminals.

In the other study, Laub and Sampson (1988) reanalyzed data from the files compiled by Sheldon Glueck and Eleanor Glueck (1950). They built 
measures of family discipline, parent-child relations, and maternal supervision from multiple sources of information. The variables indicated that childrearing processes bore strong relations to juvenile delinquency, as measured through official records. Laub and Sampson concluded that "family process and delinquency are related not just independent of traditional sociological controls, but of biosocial controls as well" (p. 374).

Other researchers have focused on different parts of the child-rearing process. Selection seems to be more a matter of style than a result of considered evidence. In reviewing studies of family socialization, Loeber and Stouthamer-Loeber (1986) concluded that parental neglect had the largest impact on crime. They also suggested the possibility of a sleeper effect from socialization practices, although they noted that reports by different members of the family have little convergence.

Problems in collecting information make the few extant longitudinal data sets that include family interactions particularly valuable. The Cambridge-Somerville Youth Study data provided evidence about childhood milieu and family interaction collected during childhood. The data were based on observations of family processes by a variety of people over a period of several years.

Prior analyses of the data, based on a follow-up when the men were in their late twenties, have provided evidence of predictive validity for many of the measures. The results of these earlier studies suggested that child-rearing practices mediate the conditions under which sons follow the footsteps of criminal fathers (J. McCord and W. McCord, 1958). They showed that child-rearing practices are correlated with concurrent aggressive behavior among nondelinquents (W. McCord et al., 1961) and contribute to promoting antisocial directions for aggressive behavior (J. McCord et al., 1963a). Analyses also indicated that the stability of family environments mediated results of maternal employment on concurrent characteristics of dependency and sex anxiety; only among unstable families did maternal employment seem to contribute to subsequent delinquency (J. McCord et al., 1963b). Probably the most critical test of the predictive worth of the coded variables appeared in the analyses of their relation to alcoholism (W. McCord and J. McCord, 1960). Spurred on by these results, I collected additional information from and about the men two decades later.

Prior analyses from this extended data base have suggested that parental affection acts as a protective factor against crime (J. McCord, 1983b, 1986) and alcoholism (J. McCord, 1988). Analyses also suggested that how parents responded to their son's aggressive behavior influenced whether early aggression continued through adolescence and emerged as criminal behavior (J. McCord, 1983b).

In tracing the comparative results of child abuse, neglect, and rejection, analyses indicated both that parental rejection was more criminogenic than 
either abuse or neglect and that vulnerability to alcoholism, mental illness, early death, and serious criminality was increased by having had an alcoholic, criminal, or aggressive parent (J. McCord, 1983a).

Prior analyses from these data have also shown that single-parent families are not more criminogenic than two-parent families-provided the mother is affectionate (J. McCord, 1982). Additional analyses of family structure indicated that although parental absence had a detrimental effect on delinquency, only when compounded by other family-related stresses did it have an apparent effect on serious criminal behavior, alcoholism, or occupational achievement (J. McCord, 1990).

Theories have emphasized one or another description of family life as important to healthy child development. Research concerned with bonding to, or identification with, socialized adults has focused on affection of parents for their children (e.g., Hirschi, 1969; W. McCord and J. McCord, 1959). Research based on either conditioning or dissonance theories has emphasized discipline and controls (e.g., Bandura and Walters, 1959; Baumrind, 1968, 1978, 1983; Lewis, 1981). And differential association and social learning theories give special weight to the nature of available models (e.g., Akers, 1973; Bandura and Walters, 1963; Sutherland and Cressey, 1974).

Because criminologists have rarely gone beyond describing home environments in globally evaluative terms, the same data could be interpreted as confirming the importance of family bonding or of providing firm control. In order to distinguish among effects, equally valid and reliable measurement of the different dimensions is needed, and collinearity among the measures must be taken into account. Although it is known that child rearing influences adult criminality (J. McCord, 1979, 1983b), there is little ground for judging the extent to which one or another dimension of child rearing is important at different times. Thus, the question remains: In what ways does child rearing affect criminal behavior?

This study addresses two questions: (1) Are there particular features of child rearing that influence criminal outcomes or does only the general home atmosphere of childhood account for the relationship between conditions of socialization and crime? (2) Do similar influences operate to increase criminality at different ages?

\section{METHOD}

This study includes 232 boys who had been randomly selected for a treatment program that, although designed to prevent delinquency, included both well behaved and troubled youngsters. The boys were born between 1926 and 1933. They lived in congested, urban areas near Boston, Massachusetts. Counselors visited their homes about twice a month over a period of more 
than five years. Typically, the boys were between their tenth and sixteenth birthdays at the time of the visits.

One emphasis of the youth study was on developing sound case reports. Staff meetings included discussion of cases not only from the perspective of treatment but also to provide rounded descriptions of the child's life circumstances. After each visit with a boy or his parents, counselors dictated reports about what they saw and heard (see Powers and Witmer, 1951). The reports from visits to the boys' homes provided the raw material for subsequent analyses.

\section{CHILD-REARING VARIABLES}

In 1957, records were coded to describe the 232 families of the 253 boys who had remained in the program after an initial cut in 1941 (see W. McCord and J. McCord, 1960). Codes included ratings of family structure, family conflict, esteem of each parent for the other, parental supervision and disciplinary characteristics, parental warmth, self confidence, role, and aggressiveness. Codes also included parental alcoholism and criminality. The coding was designed for global assessments; this type of rating helps to circumvent problems that would occur when measures depend on specific items of information that might be missing from any particular data collection effort.

Among the 232 families, 130 were intact through the boys' sixteenth year. There were 60 families in which mothers were not living with a man; 23 fathers had died and 37 were living elsewhere. There were 30 families with mother substitutes and 29 with father substitutes, including 17 in which both natural parents were absent. Information about absent parents came from their concurrent interactions with the boys or their mothers. Thirteen substitute fathers and 13 substitute mothers were rated.

Rating for the mother's self-confidence were based on how she reacted when faced with problems. If she showed signs of believing in her ability to handle problems, she was rated as self-confident $(N=66)$. Alternative ratings were "no indication," "victim or pawn," and "neutral."

The attitude of a parent toward the boy was classified as "affectionate" if that parent interacted frequently with the child without being generally critical. Among the parents, 110 mothers and 59 fathers were rated as affectionate. Alternative classifications were "passively affectionate" (if the parent was concerned for the boy's welfare, but there was little interaction), "passively rejecting" (if the parent was unconcerned for the boy's welfare and interacted little), "actively rejecting" (if the parent was almost constantly critical of the boy), "ambivalent" (if the parents showed marked alternation between affection and rejection of the child), and "no indication."

Parental conflict reflected reports of disagreements about the child, values, money, alcohol, or religion. Ratings could be "no indication," "apparently 
none," "some," or "considerable." Parents were classified as evidencing $(N$ $=75$ ) or not evidencing considerable conflict.

A rating of each parent's esteem for the other was based on evidence indicating whether a parent showed respect for the judgment of the other. Ratings could be "no indication," "moderate or high," or "low." In this study, each parent was classified as showing or not showing moderate or high esteem for the other. Almost an equal number of mothers $(N=109)$ and fathers $(N=106)$ revealed relatively high esteem for their spouse.

Maternal restrictiveness was rated as "subnormal" if a mother permitted her son to make virtually all his choices without her guidance $(N=83)$. Alternative ratings were "no indication," "normal," and "overly restrictive."

Parental supervision was measured by the degree to which the boy's activities after school were governed by an adult. Supervision could be rated "present" $(N=132)$ or, alternatively, "sporadic," "absent," or "no information."

Demands placed on a child were considered "high" if they involved doing well at school and performing tasks at home or if they included unusually high standards for either school or home $(N=58)$. Alternative ratings were "moderate," "low," and "no information."

Discipline by each parent was classified into one of six categories. "Consistently punitive, including very harsh verbal abuse," identified a parent who used physical force to control the boy. A parent who used praise, rewards, or reasoning to control the boy was rated as "consistent, nonpunitive." Alternative categories were "erratically punitive," "inconsistent, nonpunitive," "extremely lax, with almost no use of discipline," and "no information." Fathers were difficult to classify for consistency, so for this analysis, their discipline was coded as "punitive" $(N=39)$ or "other." Mother's discipline was coded as "consistent and nonpunitive" $(N=70)$, or "other."

A mother's role in the family was classified as "leader," "dictator," "martyr," "passive," "neglecting," or "no indication." The leadership role involved participating in family decisions. Mothers in this analysis were classified either as being $(N=144)$ or not being leaders.

The aggressiveness of each parent was rated as "unrestrained" if that parent regularly expressed anger by such activities as shouting abuses, yelling, throwing or breaking things, or hitting people. Thirty-seven fathers and 23 mothers were rated as aggressive. Alternative classifications were "no indication," "moderately aggressive," or "greatly inhibited."

To estimate the reliability of the coding, two raters independently read a $10 \%$ random sample of the cases. Agreement for those ratings ranged from $76 \%$ to $96 \%$. Since chance agreement between raters varies in relation to distribution, Scott's (1955) interrater reliability coefficient, pi, was computed 
to indicate improvement over chance.1 (See Table 1.)

Table 1. Interrater Reliability: Dichotomous Variables ( 2 raters on $10 \%$ random sample)

\begin{tabular}{lcc}
\hline Characteristic & $\begin{array}{c}\text { Percent } \\
\text { Agreement }\end{array}$ & $\begin{array}{c}\text { Scott's } \\
\text { Pi* }^{*}\end{array}$ \\
\cline { 3 - 4 } Mother's Self-Confidence & 84 & .60 \\
Mother's Discipline & 84 & .62 \\
Mother's Attitude to Son & 84 & .68 \\
Mother's Leadership & 96 & .91 \\
Father's Attitude to Son & 84 & .57 \\
Father's Esteem for Mother & 84 & .68 \\
Mother's Esteem for Father & 88 & .76 \\
Father's Aggressiveness & 84 & .41 \\
Family Conflict & 80 & .55 \\
Boy's Supervision & 88 & .76 \\
Demands for Boy & 76 & .35 \\
Mother's Restrictiveness & 84 & .65 \\
Mother's Aggressiveness & 92 & .56 \\
Father's Discipline & 88 & .52 \\
\hline
\end{tabular}

* $\mathrm{Pi}=\left(P_{\mathrm{o}}-P_{\mathrm{e}}\right) /\left(1-P_{\mathrm{e}}\right) . P_{\mathrm{o}}=$ percent agreement observed.

$P_{\mathrm{r}}=(p)^{2}+(q)^{2}$, where $p=$ proportion having the characteristic and $q=1-p$.

Correlation among the measures of child rearing showed that supervision was strongly related to each of the other measures. Only mothers' aggression and fathers' discipline were not strongly correlated with the other measures. As Table 2 indicates, correlations among some of the variables suggested that they might be measures of similar dimensions.

A clustering procedure, Varclus (SAS, 1985), was used to identify the dimensional structure of the 14 variables. The procedure searches for unidimensional factors in terms of combinations of variables that will maximize variance among cluster centroids. The first cluster included (in order of contribution) mother's discipline, self-confidence, affection for her son, and role. The factor appeared to represent Mother's Competence. A second

1. Scott's pi differs from kappa (Cohen, 1960) regarding expected values. Whereas kappa assumes fixed marginals for both raters, pi assumes only a single distribution. 


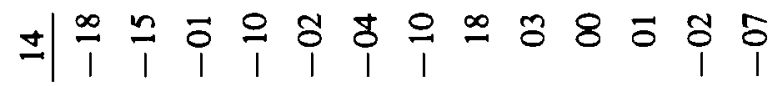

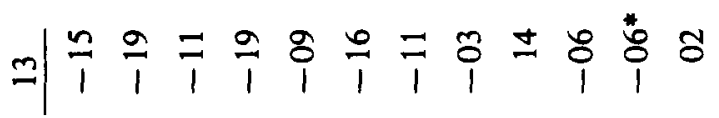

$$
\begin{aligned}
& \text { ㄴำ } \\
& =\mid \begin{array}{c}
* \\
\text { 의 }
\end{array}
\end{aligned}
$$

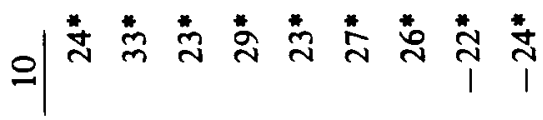

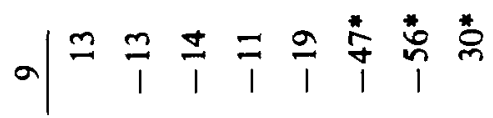

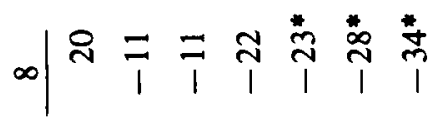

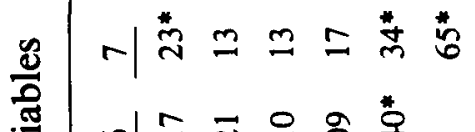

$$
\begin{aligned}
& \text { 부 } \\
& n \mid \pm m \stackrel{\infty}{\sim} \tilde{o} \\
& +\mid \stackrel{*}{*} \stackrel{*}{*} \\
& m \mid \stackrel{*}{*} \stackrel{*}{m} \\
& \text { N) } \stackrel{*}{+} \\
& \text { 哭 } \\
& \text { i } \\
& \text { 苞 }
\end{aligned}
$$

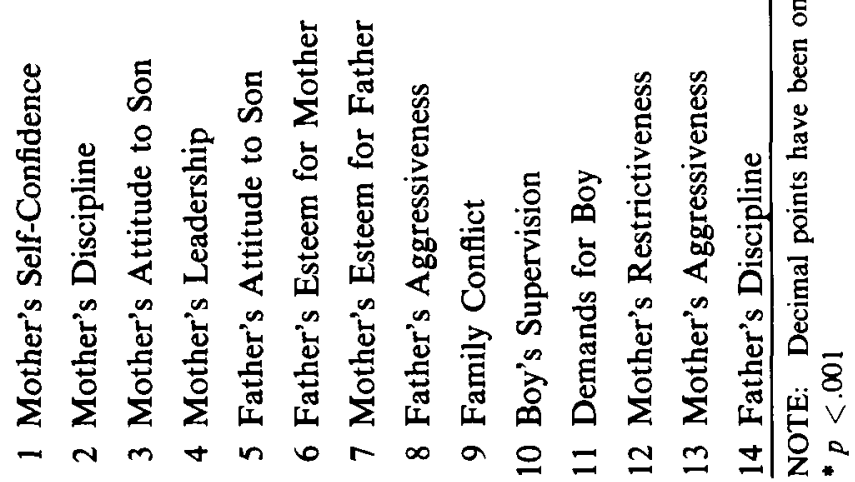


dimension included (in order of contribution) mother's esteem for the father, father's esteem for the mother, parental conflict, father's affection for his son, and father's aggressiveness. The factor appeared to represent Father's Interaction with the family. A third dimension included (in order of contribution) maternal restrictiveness, supervision, and demands. The factor represented Family Expectations. A fourth dimension included father's punitiveness and mother's aggressiveness, weighted in opposite directions. The factor appeared to measure something like Disciplinarian. This factor was dropped, however, because $75 \%$ of the families scored at the midpoint. Table 3 shows descriptive characteristics of the clusters representing Mother's Competence, Father's Interaction, and Family Expectations.

Table 3. Cluster Analysis

\begin{tabular}{|c|c|c|c|}
\hline \multirow[b]{2}{*}{ Group Variable } & \multicolumn{2}{|c|}{$R^{2}$} & \multirow{2}{*}{$\begin{array}{c}\text { Scoring } \\
\text { Coefficient }\end{array}$} \\
\hline & Highest & Second & \\
\hline \multicolumn{4}{|l|}{ Mother's Competence } \\
\hline Consistent Discipline & .553 & .104 & .386 \\
\hline Self-Confidence & .479 & .087 & .359 \\
\hline Affection for Son & .472 & .084 & .357 \\
\hline Role & .422 & .054 & .337 \\
\hline \multicolumn{4}{|l|}{ Father's Interaction } \\
\hline Father's Esteem for Mother & .669 & .053 & .320 \\
\hline Mother's Esteem for Father & .720 & .058 & .332 \\
\hline Parental Conflict & .532 & .049 & -.286 \\
\hline Father's Affection for Son & .323 & .045 & .222 \\
\hline Father's Aggressiveness & .312 & .050 & -.219 \\
\hline \multicolumn{4}{|l|}{ Family Expectations } \\
\hline Mother's Restrictiveness & .710 & .096 & -.478 \\
\hline Supervision & .692 & .154 & .472 \\
\hline Demands & .360 & .054 & .341 \\
\hline \multicolumn{4}{|c|}{ Correlations } \\
\hline & A & B & C \\
\hline A Mother's Competence & 1.00 & & \\
\hline B Father's Interaction & 0.29 & 1.00 & \\
\hline C Family Expectations & 0.41 & 0.31 & 1.00 \\
\hline
\end{tabular}

The predictive validity of home observations had been proven in prior studies, but problems of collinearity precluded using the individual scales for the purpose of detecting differential impact. The Varclus clustering procedure 
reduced collinearity to acceptable levels, but a conservative view would recognize the resultant measures as having only ordinal properties. To stabilize and simplify the scales, items in each factor were given equal weights and scored so that higher scores represent more socially desirable behaviors: greater mother's competence; more approving, less aggressive father's interaction; and higher family expectations. Scores on Mother's Competence ranged from 0 to +4 ; on Father's Interaction, from -2 to +3 ; and on Family Expectations, from -1 to +2 . Each factor was divided as close to the median as possible so that a family could be described as high or low in terms of each of the variables.

\section{FOLLOW UP MEASURES}

Between 1975 and 1980, when they ranged from 45 to 53 years in age, the former youth study participants were retraced. Twenty-four were found through their death records. ${ }^{2}$ Police and court records had been collected in 1948. Those records of juvenile delinquency were combined with records gathered in 1979 from probation departments in Massachusetts and in other states to which the men had migrated.

The measure of criminality depended on official records of convictions. Such records do not reflect all crimes committed (Murphy et al., 1946), but they do appear to identify those who commit serious crimes and those who break the law frequently (Morash, 1984). In addition, several studies show convergence between results from official records and from well-designed selfreporting instruments for measuring serious criminality (Elliott and Ageton, 1980; Farrington, 1979; Hindelang et al., 1979; Reiss and Rhodes, 1961).

A boy was considered a juvenile delinquent if he had been convicted for an index crime prior to reaching the age of 18 years. Fifty boys had been convicted for such serious crimes as auto theft, breaking and entering, and assault. Of the 50 juvenile's convicted for serious crimes, 21 also were convicted for serious crimes as adults; additionally, 29 men not convicted as juveniles were convicted for at least one index crime as an adult.

The strength of relationships was tested using chi-square. Catmod (SAS, 1985), a method for analyzing categorical data, was used to detect the impact of family interaction on delinquency and on adult criminality. Catmod uses a log-linear procedure that fits a linear model on generalized logits. Where analysis of variance estimates are based on individual scores, the log-linear procedure estimates are based on cell frequencies.

2. None of the subjects died before the age of 20 . Of those who died in their twenties, nine had no convictions and one was convicted only as a juvenile. Of those who died in their thirties, three had no convictions, two were convicted only as juveniles, and two were convicted only as adults. Of those who died in their forties, three were not convicted, two were convicted only as adults, and two were convicted both as juveniles and as adults. 


\section{RESULTS}

Comparisons for the impact of child rearing showed that Mother's Competence, Father's Interaction with the family, and Family Expectations were related to juvenile delinquency. Considered separately, poor child rearing in each of these domains reliably increased risk of delinquency (Table 4).

Table 4. Child-Rearing Variables and Juvenile Delinquency (Percent who were juvenile delinquents)

\begin{tabular}{lrrrrr}
\hline & & & & Prob. \\
Mother's Competence = High & $(123)$ & 11 & Low (109) 34 & .000 \\
Self-Confident & $(66)$ & 8 & not $(166)$ & 27 & .001 \\
Consistent Nonpunitive & $(70)$ & 9 & not (162) 27 & .002 \\
Affectionate & $(110)$ & 10 & not (122) 32 & .000 \\
A Leader & $(144)$ & 16 & not (88) 31 & .008 \\
Father's Interaction = Good & $(123) 14$ & Bad (109) 30 & .002 \\
Esteem for Mother High & $(106)$ & 9 & not (126) 32 & .000 \\
Mother's Esteem for Father High & $(109) 12$ & not (123) 30 & .001 \\
Family Conflict Much & $(75) 35$ & not $(157) 15$ & .001 \\
Aggressive & $(37) 38$ & not $(195) 18$ & .009 \\
Affectionate & $(59)$ & 5 & not (173) 27 & .000 \\
Family Expectations $=$ High & $(125)$ & 11 & Low (107) 34 & .000 \\
Mother Control Little & $(83) 35$ & not (149) 14 & .000 \\
Boy Supervised & $(132)$ & 12 & not (100) 34 & .000 \\
Demands for Boy High & $(58) 10$ & not (174) 25 & .017 \\
\hline
\end{tabular}

NOTE: Numbers in parentheses are $N$ s.

Joint effects of poor child rearing can be seen by examining their combinations in relation to juvenile delinquency. Only $5 \%$ of the boys reared by competent mothers in families with good paternal interaction and high expectations had become delinquents. In contrast, almost half (47\%) had become delinquents among those who had been raised by incompetent mothers in homes that had poor paternal interaction and low expectations (Table 5). 
Table 5. Family Constellations and Juvenile Delinquency (Percent delinquent in each type of family)

\begin{tabular}{|c|c|c|c|c|c|}
\hline \multirow{4}{*}{$\begin{array}{l}\text { Father's Interaction } \\
\text { Bad }\end{array}$} & & \multicolumn{4}{|c|}{ Mother's Competence } \\
\hline & & \multicolumn{2}{|l|}{ Low } & \multicolumn{2}{|c|}{ High } \\
\hline & \multicolumn{3}{|c|}{ Family Expections } & & \\
\hline & Weak & (38) 47 & & (24) & 29 \\
\hline Bad & Strong & (25) 24 & & (22) & 9 \\
\hline Good & Weak & (29) 34 & & (16) & 6 \\
\hline \multirow[t]{3}{*}{ Good } & Strong & (17) 18 & & (61) & 5 \\
\hline & & \multicolumn{4}{|c|}{ Analysis of Variance (CATMOD) } \\
\hline & & D.F. & Chi Sq. & & Prob. \\
\hline Intercept & & 1 & 55.65 & & .0001 \\
\hline Mother's Competence & & 1 & 8.72 & & .0031 \\
\hline Father's Interaction & & 1 & 3.67 & & .0554 \\
\hline Family Expectations & & 1 & 8.60 & & .0034 \\
\hline Residual & & 4 & 1.32 & & .8574 \\
\hline
\end{tabular}

NOTE: Numbers in parentheses are $N$ 's.

Serious criminality as a juvenile was strongly related to both the mother's competence and to family expectations for the boy. Together, these accounted for $12 \%$ of the variance in juvenile delinquency, $p=.0001$. Father's poor interaction with the family showed a weaker relationship with juvenile delinquency; it accounted for an additional $1.5 \%$ of the variance, $p=.0617$.

A different picture emerges from analyses of the impact of child-rearing variables on adult criminality (see Table 6). ${ }^{3}$ Father's interaction with the family increased in importance. With the exception of affection, each of the variables contributing to this dimension was related to adult criminality. The impact of the mother's competence had weakened-only the mother's selfconfidence clearly contributed to adult criminality. The dimension of family expectations was not reliably related to adult convictions, although supervision and maternal control apparently had enduring effects. The categorical analysis of variance, controlling collinearity, indicated that only the father's interactions bore a significant independent relationship to adult criminality (Table 7).

3. The range in age among the 20 who had died prior to the follow-up and did not have criminal records as adults was 20 to 50 years. The median age was 39 . Only six were under age 25 . Because there was no attempt to ascertain rates of criminality, no correction was attempted for time of "exposure." 
Table 6. Child-Rearing Variables and Adult Criminality (Percent who were adult criminals)

\begin{tabular}{lrrlll}
\hline & & & & Prob. \\
Mother's Competence = High & $(123)$ & 15 & Low & $(109) 27$ & .036 \\
Self-Confident & $(66)$ & 6 & not & $(166) 27$ & .001 \\
Consistent Nonpunitive & $(70) 13$ & not & $(162) 24$ & NS \\
Affectionate & $(110) 15$ & not & $(122) 25$ & NS \\
A Leader & $(144) 17$ & not & $(88) 26$ & NS \\
Father's Interaction = Good & $(123) 14$ & Bad & $(109) 28$ & .006 \\
Esteem for Mother High & $(106) 11$ & not & $(126) 29$ & .001 \\
Mother's Esteem for Father High $1(109) 13$ & not & $(123) 28$ & .005 \\
Family Conflict Much & $(75) 32$ & not & $(157) 15$ & .003 \\
Aggressive & $(37) 43$ & not & $(195) 16$ & .000 \\
Affectionate & $(59) 15$ & not & $(173) 23$ & NS \\
Family Expectations = High & $(125) 18$ & Low & $(107) 24$ & NS \\
Mother Control Little & $(83) 28$ & not & $(149) 17$ & .049 \\
Boy Supervised & $(132) 15$ & not & $(100) 28$ & .017 \\
Demands for Boy High & $(58) 12$ & not & $(174) 24$ & NS \\
\hline
\end{tabular}

NOTE: Numbers in parentheses are $N$ s.

Table 7. Family Constellations and Adult Criminality (Percent criminal in each type of family)

\begin{tabular}{|c|c|c|c|c|c|}
\hline \multirow{4}{*}{$\begin{array}{l}\text { Father Interaction } \\
\text { Bad }\end{array}$} & & \multicolumn{4}{|c|}{ Mother's Competence } \\
\hline & & \multicolumn{2}{|l|}{ Low } & \multicolumn{2}{|c|}{ High } \\
\hline & \multicolumn{2}{|c|}{ Family Expections } & & \multirow[b]{2}{*}{$(24$} & \\
\hline & Weak & (38) 34 & & & 29 \\
\hline Bad & Strong & (25) 32 & & $(22)$ & 14 \\
\hline Good & Weak & (29) 14 & & (16) & 13 \\
\hline \multirow[t]{3}{*}{ Good } & Strong & (17) 24 & & (61) & 11 \\
\hline & & \multicolumn{4}{|c|}{ Analysis of Variance (CATMOD) } \\
\hline & & D.F. & Chi Sq. & & Prob. \\
\hline Intercept & & 1 & 63.44 & & .0001 \\
\hline Mother's Competence & & 1 & 2.09 & & NS \\
\hline Father's Interaction & & 1 & 4.88 & & .0271 \\
\hline Family Expectations & & 1 & 0.12 & & NS \\
\hline Residual & & 4 & 2.18 & & .7028 \\
\hline
\end{tabular}

NOTE: Numbers in parentheses are $N$ s. 
Conviction as a juvenile was related to being convicted as an adult. As noted above, among the 50 boys who had been juvenile delinquents, 21 (42\%) had been convicted for serious crimes as adults. In contrast, among 182 boys who had not been convicted for serious crimes as juveniles, $27(15 \%)$ had been convicted for serious crimes as adults, $X_{(1)}^{2}=17.64, p<.001$.

To test the degree to which paternal interaction independently influenced adult crime above and beyond effects through juvenile delinquency, juvenile delinquency and the three child-rearing dimensions were introduced into a stepwise discriminant function analysis (Table 8). The results show that juvenile delinquency accounted for $7.6 \%$ of the variance in adult criminality, $p=.0001$. The father's interactions during childhood accounted for an additional $1.8 \%, p<.0438$. None of the other child-rearing variables approached a significant contribution to variance in adult criminality (with a criterion of entry set at $p<.15$ ) once juvenile criminality had been taken into account.

Table 8. Predictors of Adult Criminality (stepwise discriminant analysis)

\begin{tabular}{|c|c|c|c|c|}
\hline Step & Variable & Partial $r^{2}$ & $F$ & Prob. $>F$ \\
\hline 1 & Juvenile Delinquency & .076 & 18.926 & .0001 \\
\hline 2 & Father's Interaction & .018 & 4.109 & .0438 \\
\hline
\end{tabular}

\section{SUMMARY AND DISCUSSION}

This study reexamined the ways in which family interactions during childhood influence criminal behavior. By considering families whose socioeconomic backgrounds were similar, it was possible to look beyond effects of poverty, social disorganization, and blighted urban conditions.

Case records based on repeated visits to the homes of 232 boys allowed analyses that included the dynamics of family interactions. The variables resulting from observations in the homes were reduced to three dimensions in order to minimize problems of collinearity. A reasonable conclusion from the data is that the mother's competence and family expectations influenced the likelihood that a son became a juvenile delinquent.

Competent mothers seem to insulate a child against criminogenic influences even in deteriorated neighborhoods. Competent mothers were self-confident and provided leadership; they were consistently nonpunitive in discipline and affectionate. Coupled with high family expectations, maternal 
competence seems to reduce the probability that sons become juvenile delinquents. The influence of these child-rearing conditions on adult criminality appears to be largely through their impact on juvenile delinquency.

Compared with the mother's influences, the father's interactions with his family appeared less important during the juvenile years. Father's interactions with the family became more important, however, as the boys matured.

Fathers who interact with their wives in ways exhibiting high mutual esteem, who are not highly aggressive, and who generally get along well with their wives provide models for socialized behavior. Conversely, fathers who undermine their wives, who fight with the family, and who are aggressive provide models of antisocial behavior. Both types of fathers, it seems, teach their sons how to behave when they become adults.

The evidence from this study raises doubts about two currently prevalent views. One view holds that regardless of the age of the criminal, crime is merely a particular symptom of a single underlying "disorder." The other view holds that causes of crime are basically the same at all ages. This study indicates that the causes of juvenile crime are different from those of adult criminality. Juvenile delinquency might be explained through elements of control, as represented by maternal competence and high expectations, but adult criminality appears to add a component based on role expectations. If these interpretations are correct, criminality cannot be attributed to a single type of cause, nor does it represent a single underlying tendency.

\section{REFERENCES}

Akers, R.L

1973 Deviant Behavior: A Social Learning Approach. Belmont, Calif.: Wadsworth.

Aristotle

1941 Ethica Nicomachea, trans. W.D. Ross. In R. McKeon (ed.), The Basic Works of Aristotle. New York: Random House.

Bachman, J.G. and P.M. O'Malley

1984 The Youth in Transition Project. In S.A. Mednick, M. Harway, and K.M. Finello (eds.), Handbook of Longitudinal Research. New York: Praeger.

Bacon, M.K., I.L. Child, and H. Barry, Jr.

1963 A cross-cultural study of correlates of crime. Journal of Abnormal and Social Psychology 66:291-300.

Bandura, A. and R.H. Walters

1959 Adolescent Aggression. New York: Ronald.

1963 Social Learning and Personality Development. New York: Holt, Rinehart \& Winston.

Baumrind, D.

1968 Authoritarian vs. authoritative parental control. Adolescence 3:255-272.

1978 Parental disciplinary patterns and social competence in children. Youth and Society 9(3):239-276. 
1983 Rejoinder to Lewis's reinterpretation of parental firm control effects: Are authoritative families really harmonious? Psychological Bulletin 94(1):132-142.

Bowlby, J.

1940 The influence of early environment on neurosis and neurotic character. International Journal of Psychoanalysis 21:154.

1951 Maternal care and mental health. Bulletin of the World Health Organization 3:355-534.

Burt, C.

1925 The Young Delinquent. New York: Appleton \& Co.

Cernkovich, S.A. and P.C. Giordano

1987 Family relationships and delinquency. Criminology 25(2):295-319.

Cohen, J.

1960 A coefficient of agreement for nominal scales. Educational and Psychological Measurement 20:37-46.

Dean, A.L., M.M. Malik, W. Richards, and S.A. Stringer

1986 Effects of parental maltreatment on children's conceptions of interpersonal relationships. Developmental Psychology 22(5):617-626.

Dodge, K.Q. and D.R. Somberg

1987 Hostile attributional biases among aggressive boys are exacerbated under conditions of threats to the self. Child Development 58:213-224.

Dornbusch, S.M., J.M. Carlsmith, S.J. Bushwall, P.L. Ritter, H. Leiderman, A.H. Hastorf, and R.T. Gross

1985 Single parents, extended households, and the control of adolescents. Child Development 56:326-341.

Eich, E., S. Rachman, and C. Lopatka

1990 Affect, pain, and autobiographical memory. Journal of Abnormal Psychology 99(2):174-178.

Elliott, D.S. and S.S. Ageton

1980 Reconciling race and class differences in self-reported and official estimates of delinquency. American Sociological Review 45:95-110.

Eron, L.D., T.J. Banta, L.O. Walder, and J.H. Laulicht

1961 Comparison of data obtained from mothers and fathers on child-rearing practices and their relation to child aggression. Child Development 32(3):455-472.

Farrington, D.P.

1979 Environmental stress, delinquent behavior, and convictions. In I.G. Sarason and C.D. Spielberger (eds.), Stress and Anxiety. Vol. 6. New York: John Wiley \& Sons.

Fenichel, $\mathrm{O}$.

1945 The Psychoanalytic Theory of Neurosis. New York: Norton.

Forehand, R., K.C. Wells, and E.T. Sturgis

1978 Predictors of child noncompliant behavior in the home. Journal of Consulting and Clinical Psychology 46(1):179. 
Freud, S.

1953 Three Essays on the Theory of Sexuality. In Standard Edition. Vol. VII. London: Hogarth.

Glueck, S. and E.T. Glueck

1950 Unraveling Juvenile Delinquency. New York: Commonwealth Fund.

Goldfarb, W.

1945 Psychological privation in infancy and subsequent adjustment. American Journal of Orthopsychiatry 15:247-255.

Goode, W.J.

1956 After Divorce. Glencoe, Ill.: Free Press.

Hagan, J., A.R. Gillis, and J. Simpson

1985 The class structure of gender and delinquency: Toward a power-control theory of common delinquent behavior. American Journal of Sociology 90:1151-1178.

Hindelang, M.J., T. Hirschi, and J.G. Weis

1979 Correlates of delinquency: The illusion of discrepancy between self-report and official measures. American Sociological Review 44:995-1014.

Hirschi, T.

1969 Causes of Delinquency. Berkeley: University of California Press.

1983 Crime and the family. In J.Q. Wilson (ed.), Crime and Public Policy. San Francisco: Institute for Contemporary Studies.

Hoffman, L.W.

1975 Effects on child. In L.W. Hoffman and F.I. Nye (eds.), Working Mothers. San Francisco: Jossey-Bass.

Jensen, G.F. and D. Brownfield

1983 Parents and drugs. Criminology 21(4):543-555.

Kellogg, R.T.

1980 Is conscious attention necessary for long-term storage. Journal of Experimental Psychology 6(4):379-390.

Lamb, M.E.

1976 The role of the father: An overview. In M.E. Lamb (ed.), The Role of the Father in Child Development. New York: John Wiley \& Sons.

Larzelere, R.E. and G.R. Patterson

1990 Parental management: Mediator of the effect of socioeconomic status on early delinquency. Criminology 28(2):301-323.

Laub, J.H. and R.J. Sampson

1988 Unraveling families and delinquency: A reanalysis of the Gluecks' data.

Criminology 26(3):355-380.

Levy, D.

1937 Primary affect hunger. American Journal of Psychiatry 94:643-652.

Lewis, C.

1981 The effects of parental firm control: A reinterpretation of findings.

Psychological Bulletin 90(3):547-563.

Liska, A.E. and M.D. Reed

1985 Ties to conventional institutions and delinquency: Estimating reciprocal effects. American Sociological Review 50(Aug):547-560. 
Locke, J.

1693 Some Thoughts Concerning Education. Vol. 8, Collected Works. 9th ed.

London: T. Longman

Loeber, R. and M. Stouthamer-Loeber

1986 Family factors as correlates and predictors of juvenile conduct problems and delinquency. In M. Tonry and N. Morris (eds.), Crime and Justice. Vol. 7. Chicago: University of Chicago Press.

Maccoby, E.E.

1958 Effects upon children of their mothers' outside employment. In National

Manpower Council, Work in the Lives of Married Women. New York:

Columbia University Press.

McCord, J.

1979 Some child-rearing antecedents of criminal behavior in adult men. Joumal of Personality and Social Psychology 37:1477-1486.

1982 A longitudinal view of the relationship between paternal absence and crime. In J. Gunn and D.P. Farrington (eds.), Abnormal Offenders, Delinquency, and the Criminal Justice System. Chichester: John Wiley \& Sons.

1983a A forty year perspective on effects of child abuse and neglect. Child Abuse and Neglect 7:265-270.

1983b A longitudinal study of aggression and antisocial behavior. In K.T. Van Dusen and S.A. Mednick (eds.), Prospective Studies of Crime and Delinquency. Boston: Kluwer-Nijhoff.

1986 Instigation and insulation: How families affect antisocial aggression. In J. Block, D. Olweus, and M.R. Yarrow (eds.), Development of Antisocial and Prosocial Behavior. New York: Academic Press.

1988 Identifying developmental paradigms leading to alcoholism. Journal of Studies on Alcohol 49(4):357-362.

1990 Longterm effects of parental absence. In L. Robins and M. Rutter (eds.), Straight and Devious Pathways from Childhood to Adulthood. New York: Cambridge University Press.

McCord, J. and W. McCord

1958 The effects of parental role model on criminality. Journal of Social Issues 14(3):66-75.

1962 Cultural stereotypes and the validity of interviews for research in child development. Child Development 32(2):171-185.

McCord, J., W. McCord, and A. Howard

1963a Family interaction as antecedent to the direction of male aggressiveness. Journal of Abnormal and Social Psychology 66:239-242.

McCord, J., W. McCord, and E. Thurber

1963b The effects of maternal employment on lower class boys. Journal of Abnormal \& Social Psychology 67(1):177-182.

McCord, W. and J. McCord

1959 Origins of Crime. New York: Columbia University Press.

1960 Origins of Alcoholism. Stanford, Calif.: Stanford University Press.

McCord, W., J. McCord, and A. Howard

1961 Familial correlates of agression in nondelinquent male children. Journal of Abnormal \& Social Psychology 1:79-93. 
Miller, W.B.

1958 Lower class culture as a generating milieu of gang delinquency. Journal of Social Issues 14:5-19.

Morash, M.

1984 Establishment of a juvenile police record: The influence of individual and peer group characteristics. Criminology 22:97-111.

Murdock, G.P.

1949 Social Structure. New York: Macmillan.

Murphy, F.J., M.M. Shirley, and H.L. Witmer

1946 The incidence of hidden delinquency. American Journal of Orthopsychiatry 16:686-696.

Newell, H.W.

1934 The psycho-dynamics of maternal rejection. American Journal of Orthopsychiatry $4: 387-401$.

1936 A further study of maternal rejection. American Journal of Orthopsychiatry 6:576-589.

Nye, F.I.

1958 Family Relationships and Delinquent Behavior. New York: John Wiley \& Sons.

1959 Maternal employment and the adjustment of adolescent children. Marriage and Family Living 21(August):240-244.

Parsons, T. and R.F. Bales

1955 Family, Socialization and Interaction Process. Glencoe, Ill.: Free Press.

Plato

Laws, trans. B. Jowett. In the Dialogues of Plato (1937). N.Y.: Random House.

Powers, E. and H. Witmer

1951 An Experiment in the Prevention of Delinquency: The CambridgeSomerville Youth Study. New York: Columbia University Press.

Reiss, A.J., Jr., and A.L. Rhodes

1961 Delinquency and class structure. American Sociological Review 26(5):720-732.

Robins, L.N.

1966 Deviant Children Grown Up. Baltimore: Williams \& Wilkins.

SAS Institute

1985 SAS User's Guide: Statistics. 1985 ed. Cary, N.C.: SAS Institute.

Scott, W.A.

1955 Reliability of content analysis: The case of nominal scale coding. Public Opinion Quarterly 19(3):321-325.

Shaw, C. and H.D. McKay

1932 Are broken homes a causative factor in juvenile delinquency? Social Forces 10:514-524.

Sutherland, E.H. and D.R. Cressey

1974 Criminology. 1924. 9th ed. Philadelphia: Lippincott. 
van Voorhis, P., F.T. Cullen, R.A. Mathers, and C.C. Garner

1988 The impact of family structure and quality on delinquency: A comparative assessment of structural and functional factors. Criminology 26(2):235-261.

Wadsworth, $M$.

1979 Roots of Delinquency. New York: Barnes and Noble.

Weiler, L. and E. Luchterhand

1983 Family relationships of "Problem" and "Promising" youth. Adolescence 18(69):43-100.

Wells, L.E. and J.H. Rankin

1988 Direct parental controls and delinquency. Criminology 26(2):263-285.

Whiting, J.W.M., R. Kluckhohn, and A. Anthony

1958 The function of male initiation ceremonies at puberty. In E.E. Maccoby, T.M. Newcomb, and E.L. Hartley (eds.), Readings in Social Psychology. New York: Holt, Rinehart \& Winston.

Yarrow, M.R., J.D. Campbell, and R.V. Burton

1970 Recollections of childhood: A study of the retrospective method.

Monographs of the Society for Research in Child Development 35(1):1-83.

Joan McCord, Ph.D. in Sociology from Stanford University, is Professor of Criminal Justice at Temple University. Past president of the American Society of Criminology, she is vice chair of the National Research Council's Committee on Law and Justice. Her research has included studies of the etiology and prevention of juvenile crime, psychopathy, effects of child abuse, and causes of alcoholism. 